\title{
Congenital factor II deficiency
}

INSERM

\section{Source}

INSERM. (1999). Orphanet: an online rare disease and orphan drug data base. Congenital factor /l deficiency. ORPHA:325

Congenital factor II deficiency is an inherited bleeding disorder due to reduced activity of factor II (FII, prothrombin) and characterized by mucocutaneous bleeding symptoms. 